\title{
The Value Appeal and Spirit Decoding of the Films and Television Programs in the New Themes
}

\section{Zheng Xiangyang}

School of Art Design, Lanzhou Jiaotong University, Lanzhou, 730070, China

Keywords: Films and Television Programs under New Themes; Historical Themes; Value Appeal; Spirit Decoding

\begin{abstract}
The main theme of film and television works carrying political ideology and the transmission of mainstream values is a unique phenomenon in China's film and television. Depending on the localization of narrative strategies and the government's mandatory promotion, the main theme film and television works have created a prosperity. The rise of market economy has created a prosperous business culture. The popular narrative and entertainment expression of commercial culture has strongly impacted the main theme film and television creation of the single ideological narrative, resulting in the survival and competition of the theme melody creation. Based on this background, this paper draws on the theme of the main theme of the definition of film and television works. The concept of the theme is not limited to the selection of the subject matter, but only to the ideological bearing and ideological orientation of the artwork. Considering the patriotism, national unity fable and revolutionary heroism are the core of the main theme of the film and television works, this paper also takes the revolutionary historical themes of the national unity fable and revolutionary heroism, heroes and heroines as the main research object.
\end{abstract}

\section{Introduction}

The main theme film and television works are the main communicators of the mainstream values and dominant culture in our country. The main theme film and television works marked by "Made in China" constitute the unique scenery in the field of Chinese film and television creation [1]. As the narrator of national interests and the carrier of traditional values, the main theme film and television works rely on the attributes of political enlightenment and the creative strategy of localization. In the 1990s, the main film and television works obtained the mandatory promotion of national government and created a triumphant Prosperous era [2]. However, with the adjustment of national policies, emancipating the mind and seeking truth from facts, the ideology in the field of artistic creation has been loosening. Popular culture independent of the mainstream culture and elite culture has been rapidly emerging and has become the strongest voice in the market economy and culture [3]. Popularization, entertainment and commercial mass culture have strongly impacted the mainstream melody, stereotyped and ideological film and television works, which deconstruct the main theme of film and television works expressed and constructed by the mainstream values and traditional ethics. Entertainment deconstruction of popular culture leads to the prosperity of the main theme of the movie market forever, and the type of film and television drama in China is continuously enriched and diversified [4]. The competition mechanism in the film and television market is becoming more and more perfect, and the aesthetic level and aesthetic demands of the audience are constantly improving, which is an inevitable result of social transformation and market development [5]. The main them of present films and television programs directly led to the creation of the main theme film and television works, caught in the slightest gap between the political theory and business strategy expression, which opened up the difficult adversarial breakthrough of theme and entertainment, internalization and commercialization.

At the end of the 20th century, the creators of the main theme film and television field marketed diversified and commercialized narrative structures of main melody works, in order that the main melody films and TV works could revitalize their life in a highly competitive market and cultural context and obtain commercial operation and theme of the double victory [6]. The application of 
narrative tactics, such as the exuberance of ethics and the expression of the feelings of the nationalism of the country, opened the chapter of the creation of the new theme film and television. New theme film and television work through the common, dramatic expression of two kinds of order at home and abroad, deepening a simplistic and orderly humanistic theme to form a second annotation of psychological identity, and finally completed the existing state order of psychological approval.

Truth and fiction are two forms of narrative essence of dramatic arts, and the television series emphasizes dramatic conflicts, joys and sorrows with a distinctive fictional narrative style. The key to the success of a film and television work lies in whether the writer can use the appropriate narrative discourse to construct a wonderful TV script in the authenticity of the material and the fictionality of the plot. The same topics and materials by different writers to carry out different narrative discourse construction and narration often create different aesthetic style and style of narrative works.

\section{Main theme and its artistic features}

The main theme originally refers to a complete or relatively complete melody theme expressed in the movement. At the 1987 National Feature Film Directors' Conference, the concept of the theme was first introduced into the field of film and television creation: borrowing the main theme and expressing encouragement for artistic creation of the mainstream awareness of social progress.

Due to the unity of the audience's national psychology in special times, the traditional cultural enlightenment function and the audience's acceptance psychology, Chinese movies and TV series have assumed the educational functions of the traditional values and state interests since their birth and become the national ideological and Revolutionary ideology tool. For example, the movie "Mine Warfare" is a revolutionary ideological narrative of military education and patriotism.

\subsection{The Creative Context of Main Theme}

In the late 1980s, due to the adjustment of national political and economic policies and the rapid development of commodity economy, popular culture has rapidly prospered. The changes in the economic and cultural environment, the introduction of differences in ideology and values seriously affected the original social and cultural logic and cultural patterns, and formed the coexistence of the traditional basic ideologies and the differentiated ideologies, the combination of traditional ethics and exotic values Multicultural environment. Commercialized cultural logic and new narrative patterns began to take the initiative of popularizing and bringing them close to the reality and opened a new era of social and cultural logic and narrative patterns.

Tab.1 Lanzhou minors' views of current domestically produced movies

\begin{tabular}{lccc}
\hline \hline & The view of domestic movies & Number of people & $\begin{array}{c}\text { Effective percentage } \\
(\%)\end{array}$ \\
\hline 1 & The story is not attractive, not contagious & 661 & 32.24 \\
2 & No imagination and not new & 652 & $31.80 \square \square$ \\
3 & Lack of life and the plot is false & 535 & $26.10 \square \square$ \\
4 & Not bad & 474 & $23.12 \square \square$ \\
5 & Audio-visual impact is not enough and not enough shock & 429 & $20.93 \square \square$ \\
6 & Characters are too rational, difficult to agree & 425 & $20.73 \square \square$ \\
7 & Not close to our thoughts and feelings and not friendly & 390 & $19.02 \square \square$ \\
8 & Lack of Chinese characteristics that Chinese people like & 348 & $16.98 \square \square$ \\
9 & Vulgar, lack of respectable moral emotion & 189 & 9.22 \\
\hline \hline
\end{tabular}

The entertaining and carnivalistic nature brought by the commercialized cultural logic and the narrative mode, to a certain extent, has eliminated the authority of the main narrative and the seriousness of the ideology, resulting in the instability of the socially dominant cultural values and the socially individualized Psychological anxiety and disorganized values in a pluralistic sociocultural system. Social individuals urgently need a mainstream awareness and dominant culture to rebuild their own values and to ease the psychological anxiety caused by the strong impact of 
business logic. The state machine, too, hopes to pass a "speech message that incorporates the dominant ideology" to prevent the collapse of traditional values and social moral order, and to consolidate the national discourse and mainstream ideology from the perspective of cultural transmission so as to further stabilize the traditional moral order and national cultural system.

\subsection{The New Tendency of Main Theme}

After experiencing entertainment and carnivalesque film and television market, the creators of the main theme film and television works seek to find a more rational, more legal and broader version of the dominant cultural discourse by reorganizing and constructing dominant cultural discourse themselves Narrative space. Mainstream film and television writers who, pressing down the perspective of narrative, parallel to the emotional appeal of civilians, ethical emotional order to replace the political ideal of enlightenment, the heroic image of the emotional and threedimensional, hoping to get the theme of film and television narrative new students.

Since the 21st century, the narrative patterns and characteristics of the main narrative films and television narratives mainly include the following three aspects:

Transformation of Ethics: Close Narration. The so-called ethical transformation, that is, in the construction of the main theme film and television works, try to avoid the political "political" and political attitude of "appearance." In the writing of the main melody works, we replace the discourse of ethics and traditional order with the political theme with strong ideological color. Emotionalization of the hero's image, human plot of the plot structure, moral ethics and traditional emotion have become the center and core of the narrative of the main theme of film and television. After the state ideology is concealed in the traditional ethical order. Close to the narrative mode, with human and emotional perspectives, to interpret the emotional order of the spiritual world of people and patriotism, and to lay the groundwork for the climax of the hidden state ideology with a low profile attitude.

Reconstruction of Heroes: Secularized Heroes. The function of discourse is narration. Narration refers to the process of ideological reproduction that "primitives" and "symbolize" the original facts and construct various "intellectual" powers that influence audiences' thoughts and behaviors. The political discourse system of the main melody drama needs reform. The narrative function and narrative tactics of the main melody drama should be improved. The best balance should be found between the political ideology and the marketization. The ideology should be "naturalized" so that the melody of the main melody or subtle in-depth audience of the soul, for the effective occupation of cultural markets and ideological positions of public opinion, to construct and guide public opinion, to expand the social influence of national ideology, is of great significance.

\section{Main Function and characteristics of New Themes Films and Television Programs}

As a specific term under the movie art category, the theme film must have some of the functions and attributes of the film itself.

\subsection{The main function of the main theme of the movie}

Propaganda education function. The biggest and most important difference between the main theme films and other films lies in the fact that the main theme film is particularly important for the propaganda and education of ideology. This mainly refers to the principles and policies promulgated by the main theme film and the party policy so that the audience can accept the ideological content implicitly or explicitly accepted by the film while accepting the information disseminated by the film and become the object of ideological output. The most obvious sign that the propaganda and teaching work of the main melodrama finally came to be determined in the theory of the Chinese Communist Party was that Mao Zedong proposed the "two-for-one" guideline of "serving the people" and "serving the workers, peasants and soldiers" at the Yanan Forum of Literature and Art. Although our party and our country have made more specific and different interpretations of the political service functions of the main theme films in different periods, the principle of "two for one" is still the basic guideline and principle. 
Aesthetic entertainment features. Mainstream movies through the narrative content, visual modeling and sound configuration and other means of expression and technical means to enable viewers to relax and enjoy the aesthetic pleasure. As a combination of audio-visual comprehensive art, the film itself has a very prominent aesthetic entertainment. According to the five-level theory of the needs of the famous American psychologist Abraham H. Maslow, people can begin to pursue their spiritual needs when their material needs are met. The humorous and humorous character of German hominid movie Friedrich Wilhelm Murnau's 1924 film "The Most Despicable Person" is both entertaining and thought-provoking.

The function of educational cognition. The educational cognitive function of the main theme film refers not only to the audience to gain certain knowledge in the movie, but also to the main melody film itself as one of the channels for educating the audience. The main theme film discussed here includes not only feature films from the main theme films but also documentary films, science films and political films.

Among the above basic functions, propaganda and education are their most important and fundamental functions, and other functions are in a subordinate position and serve them.

\subsection{The main feature of the main theme of the movie}

In the history of the theme melody, the theme melodies show different characteristics in different social environments at different periods. Here, the author simply reviews the features related to the theme melodies under the media ecological environment:

Strict control of the state, in the ideological expression and reflection are very prominent. With the left-wing film as a symbol, the party began to manage and control the main theme film with theoretical guidance and direct or indirect intervention. Since entering the reform and opening up, the censorship system and the awards system at all levels have all embodied the ideology of the Chinese theme film. Should be said that the positive administrative intervention, strict censorship system, coupled with "Film Management Regulations" and many other laws and regulations to jointly create a distinctive ideology of the main theme of the film, so that the main theme of the film to become an important media to convey ideology of the party and the state tool.

Influenced by traditional culture, the narrative style, expression technique and propaganda strategy are more traditional. From the initial "movie concept" to the vast majority of the main theme films in China, the heroic figures can never be skipped and the story is flat and monotonous. However, it should be made clear that the blunt way of expression is only about the creative technique, not the value of the main melody itself and the necessity of its existence. Just as the moving of the plot is not the only decisive criterion for judging a good work, the criterion of judging a good main work should not be the redundancy of the story or the rigidity of the expression.

Highlight social benefits. The over-emphasis and emphasis placed on the ideology of the film by the Party and the state has led to the formation of the basic value orientation of emphasizing the propaganda and enlightenment, stressing the ideological content and highlighting the social benefits of the Chinese theme film, which are urgently needed for its aesthetic function, artistic expression and economic benefits This has led to the formation of one of the distinctive features of China's main theme film and the mainstream movie in the world.

\section{The Social Value of the New Themes Films and Television Programs}

For a long time, due to the limitation of the political system, the Chinese film and television drama has taken a unique and self-contained road to exist in a closed state, rejecting the recognition of the Western world. In the absence of international praise, but also limits the freedom of local creation. From the beginning of reform and opening up, China's ethnicity has gradually become a mainstream national complex; at the same time, the reform and opening up has also provided an international context for the creation of China's domestic mainstream film and television drama. Until the beginning of the new century, this new manifestation of national character has matured from its original embryonic development. 


\subsection{Promote social progress and prosperity of advanced culture}

Culture is a country's development of soft power and gradually rose to the most important position in the development of the country. The history of the progress of human civilization fully shows that without the active guidance of an advanced culture and without the great enrichment of the people's spiritual world and the full development of the creative spirit of the entire nation, it is impossible for a country or a nation to stand in the forest of the advanced nationalities in the world. In the face of the tide of globalization in the 21st century, all ethnic groups and cultures collide on the world stage, including foreign and indigenous people. For our country's national culture, this is an opportunity to go to the world is also an unprecedented challenge. In many theatricals and dramas, the theme melodrama can best represent our nationality, take root in the people, show the people and serve the people. Therefore, the best theme film and television drama is the best way to express the nationality on the screen. It allows people to unite in strength, let the world see China, understand China, and let the traditional Chinese virtues and the Chinese spirit sing on the stage of the world.

Tab.2 The proportion of population accessing to mass media in Lanzhou

\begin{tabular}{ccccccr}
\hline \hline Option & Television & Newspaper & Magazine & Book & Radio & Internet \\
\hline $\begin{array}{c}\text { Effective Percentage } \\
(\%)\end{array}$ & 55 & 3 & 9 & 8 & 2 & $23 \square$ \\
\hline \hline
\end{tabular}

\subsection{Enhance national patriotism}

To carry forward the national spirit with the spirit of patriotism as the spiritual treasure heritage of our Chinese nation for generations to come is also the quintessence of building a harmonious socialist culture. Through its outstanding national image, it plays a unique and huge role in efforts to cultivate the national spirit, shape the noble personality of the nation, improve the quality of the nation and arouse the enthusiasm of the public.

"The modern nation-state is an important place where citizens look for their own identity and cultural identity. So long as the state right can serve as a powerful political guarantee for the development of the modernity and enable the Chinese nation to continuously develop in the world, then the TV set by the state rights The system of national discourse will still be one of the main places where people seek the imagination of the country and is a valuable spiritual space where people can recognize each other. "In many publications, the contribution of the main theme film and television drama cannot be neglected. Even the earlier narrower nationalism strived to create an atmosphere of the Chinese sons and daughters for us. The concept of keeping children and their children deep in China is some of the most outstanding film and television dramas in recent years. As we mentioned earlier, in recent years, the main theme film and television drama has moved closer and closer to history and reality, abandoning the narrow-mindedness of that small ethnic group and affirming the role and status of other parties in order to better build a Greater China Concept.

\subsection{Promote the realization of the core values of socialism}

The nationality manifestation of the domestically produced film and television drama in the new period influences and shapes the image of national culture in the values, ethics, behavior, mental outlook and aesthetic taste of the nation. This is a special historic mission and social responsibility that the domestic mainstream melodrama plays in the new era and helps to promote the realization of the core values of socialism.

Carrying forward the excellent Chinese culture is to complete the great rejuvenation of the nation so that future generations and people all over the world can understand our national culture and excellent traditions. Carrying forward the Chinese culture and building a harmonious culture specifically to the main theme of film and television plays is to cultivate the national spirit with advanced thinking and healthy and beneficial thoughts by using all kinds of excellent and comparatively excellent works to educate the Chinese people, Build spiritual civilization so that all 
Chinese people will always maintain their spirited and upright spirit and sing the main melody of the times together.

\section{Conclusions}

China's film and television drama with China's change and development experience common ups and downs from the beginning of the development of cultural Enlightenment, which finally reflect the public aesthetic and promote the construction of a harmonious culture in different periods. The great rejuvenation of the Chinese nation is bound to accompany the prosperity of the Chinese culture without a cultural power. To a certain extent, it is a kind of cultural output with a variety of films and television dramas. This paper analyzes the basic theories and achievements of multidisciplinary such as comprehensive political science, communication science and film culture, and uses the methods of literature research, case analysis and comparative analysis to study the main ideology of the mainstream Chinese film and television drama, practical experience, difficulties and development strategies. On the basis of the aforementioned background, it reveals that there is an inherent contradiction between the dialectical unity of education and diversity, artistry and merchandising, innovation and acceptance in the development of the main theme film and television drama. The study of the attributes and dialectical unity of the theme film and television drama in China can help to deepen the existing theoretical research on the theme of Chinese drama.

\section{Acknowledgements}

The authors are grateful for the support provided fort his study by the Foundation of A Hundred Youth Talents Training Program of Lanzhou Jiaotong University \& Grassroots Party Building Projects "The Spirit of Main Theme of Film and Television Programs and Spiritual Education Decoding" (Project Number: DJ2017Z06) Stage Results of Lanzhou Jiaotong University.

\section{References}

[1] Mitchell J, Kidwell J. Changing Uses of Old and New Media in World Christianity [J]. The Wiley Blackwell Companion to World Christianity, 2016: 419-431.

[2] Blevens C L, Muyumba V K. The Value of Graphic Novels: Furthering the Cause of Information Literacy [J]. 2015.

[3] Yang J. 17. The Optimized Application and Research of Editing Technology in 4K Film Creation [J]. Boletín Técnico, ISSN: 0376-723X, 2017, 55(14).

[4] Monroe C. Black themed reality television \& racial identity: Gendered perceptions from Black college students [J]. 2015.

[5] Zhao J. From us to me: Cultural value changes from collectivism to individualism in Chinese commercials [D]. Kansas State University, 2017.

[6] Wang P. Inventing traditions: television dating shows in the People's Republic of China [J]. Media, Culture \& Society, 2017, 39(4): 504-519. 